\title{
Growing Naturally In A Postmodern Age: How Low-Income Producers Contend With organic Food Trends
}

\author{
Lina Cui ${ }^{1}$, Joseph J. Molnar ${ }^{2}$ \\ ${ }^{1}$ (Department of Agricultural Economics \& Rural Sociology, Auburn University, USA) \\ ${ }^{2}$ (Department of Agricultural Economics \& Rural Sociology, Auburn University, USA)
}

\begin{abstract}
Postmodernism emphasize the particular, the local and the diverse potential solutions to contemporary social, economic and environmental problems. The emergence of the term "organic farming" describes a distinct system of agriculture compared to conventional or industrial agriculture. U.S. farmers planning to market their products as "organic" must be certified following USDA procedures. In Alabama, most producers, with small-scale farms, prefer to sell their "natural" or "organically-oriented" products directly to the consumers without USDA certification. The study aims to understand Alabama organic (whether certified or not) farming strategies as a post-modern process. Using survey data from a sample of Alabama Low-input and Organically-Oriented producers (LIOP), we profile their production strategy dilemmas, production methods, information sources and marketing strategies. The data identify some of the postmodern ways its organic farmers struggle to adapt in the context of the modern agricultural system.
\end{abstract}

Keywords -Organic farming, small farms, postmodernism, production practices, marketing

\section{INTRODUCTION}

Postmodernism emphasize the particular, the local and the diverse potential solutions to contemporary social, economic and environmental problems. [1] Postmodernism is more open to the informal sector as the economy disaggregates, [2] but this also creates new dilemmas for the informal sector, as it is expected to solve the problems of the formal sector by becoming formal. [3] Organic farming has been one of the most popular food trends in recent years, which describes a distinct system of agriculture compared to conventional or industrial agriculture. Planting without synthetic chemical fertilizers, pesticides and genetically engineered seeds is a central value [4], as is producing without hormones and antibiotics. After 1950, U.S. agriculture entered an era of mechanization, farm size growth, reliance on chemical inputs and accelerated use of farming technology. $[3,4]$ Agricultural production entered into an era of modernity, "a diverse unity of socioeconomic changes generated by scientific and technological discoveries and innovation." [4] Organic might be considered as part of the postmodern reaction to conventional agriculture. [5, 6, 7]

This paper examines the Alabama organic production situation through the lens of modernity and postmodernity. We term those who employ organic methods or avoid using chemical inputs and additives as lowinput and organically-oriented producers (LIOP). [8, 9, 10, 11, 12] We consider low-income, organic production situations and strategy dilemmas in the context of modernity and post-modernity theory. Alabama organic production is viewed as a post-modern development in a context where modernity has not fully taken hold, profiling LIOP production practices, information sources and marketing strategies. The tensions and contradictions of this emerging segment are considered.

1.1. Modernity and Post-Modernity

Modernity implies "the progressive economic and administrative rationalization and differentiation of the social world". [13] In the postmodern era, scientific and rationalist discourses have lost some "legitimacy". [14] "Nostalgia and retro styles" are important features of postmodernism, in which culture people acquire old or traditional (pre-modern) lifestyles and put them in new contexts of life. [15

Two opposite (modern versus post-modern) perspectives that can be used to interpret organic farming - ecological modernization theory and treadmill production theory.[16, 17] Ecological modernization theory provides an optimistic perspective that development of technologies and social practices could protect the environment, while still allowing for growing prosperity within a large capitalist framework.[16] On the other hand, offers a much more pessimistic view that the competitive quest for profit and the corresponding economic expansion are not consistent with the earth's limited resources and fragile ecological systems.

Ecological modernization theory emphasizes the power of technology, which can help humans achieve ecological sustainability. [17] Many funding and labors are invested into organic practices study and technology development since government and some experts believe that last technologies would be used to conduct environmentally friendly agriculture production. [18] Second, ecological modernization theorists stress "the 
increasing importance of economic and market dynamics in ecological reform and the role of innovators, entrepreneurs and other economic agents as social carriers of ecological restructuring." [10] In other words, ecological modernization theorists welcome the intervention of bureaucracy and investment from entrepreneurs into organic farming, as they believe that market economics are compatible with environmentally sound production. [19]

On the contrary, treadmill theorists do not hold positive attitudes toward big capital's entry into organic farming. They regard governments and big agribusiness companies as the destroyers of the ideal in organic farming. According to treadmill theory, where there is profit, there is capital. Treadmill theorists anticipate that organic farming may also follow the path of industrial agriculture, where farm size increases, labor is replaced by technology, resulting in organic farmers leaving their land and diminishing rural community viability. In sum, ecological modernization theory views organic farming from modernity perspective, while treadmill production theory accesses organic farming from post-modernity view. [20]

As a researcher and participant in the organic movement, Kaltoft classified Danish organic farming/farmers as three types: 'pre-modern', 'modern' and 'postmodern'. [21] Modernity refers to "the separation of belief and rationality, religion and science, church and state, nature and culture, spheres of production and spheres of reproduction." [21] From this point of view, modern farmers are pragmatic and economic gain is their primary reason for growing organically. Making contracts with big agribusiness companies is a means for certain income. [22] As to human-nature relations, their interpretation of organic farming "is a technical solution to environmental problems related to agriculture" and they believe that environmental problems should be solved "for the sake of humans." [21]

'Post-modern' is a reaction to modernity, it concerns with the human-made behaviors about separating understanding or acting about the world. Jean Baudrillard argued, “... everything has already happened...nothing new can occur" or "there is no real world", which means that the objective reality is there, but subjective perspectives cannot discover the real world even though they are closer. This presents a challenge for the use of existing knowledge and science in understanding the world. Post-modern farmers reconsider the "meaning of organic farming, its role in global food production, farming methods..., and were critical of local extension and advisory service experts" and they "share the old core values of organic farming concerning soil fertility and close relations between producers and consumers" [21].

Post-modern is also equivalent to "late capitalism" (post-industrial, consumerist, and multitransnational capitalism. [22] Agro-food systems are involving in globalization, when we are in an era of PostFordism or Postmodernism. "Transnational corporations (TNCs) increased their economic flexibility through capital flight, decentralization of production, and the informalization of labor."[23] Postmodernism supersedes national borders. Transnational corporations reorganize their capital, material and labor from all over the world, so there are just networks and information flows in the post-modern society. Today, the organic movement is "an international social-environmental movement", its original philosophical goals and principles are to protect the environment and ensure social justice. [24] Many farmers who may or may not feel they are part of the organic movement, may share the same values as the movement to grow organically. [25] Thus, it is not clear whether their motivational perspective is post-modern or modern. [26] Table 1 compares selected aspects of modernity and post-modernity in terms of agricultural production strategies. 
Table 1. Contrasting Features of Modernity and Post-Modernity

\begin{tabular}{|c|c|c|}
\hline & Modern & Post modern \\
\hline Production & $\begin{array}{l}\text { - } \text { High-input: chemicals } \\
\text { - } \quad \text { High-yield hybrids } \\
\text { - } \quad \text { Rely on large scale, capital } \\
\text { intensive technology } \\
\text { - } \quad \text { Agribusiness, industrial farms }\end{array}$ & $\begin{array}{ll}\text { - } & \text { Low-input: organic } \\
\text { - } & \text { Preserve genetic diversity } \\
\text { - } & \text { Rely on small, appropriate } \\
& \text { technology } \\
\text { - } & \text { Community and family farms }\end{array}$ \\
\hline Information & $\begin{array}{llr}\text { Rely on institutionalized } \\
\text { information and advisory } \\
\text { service experts }\end{array}$ & 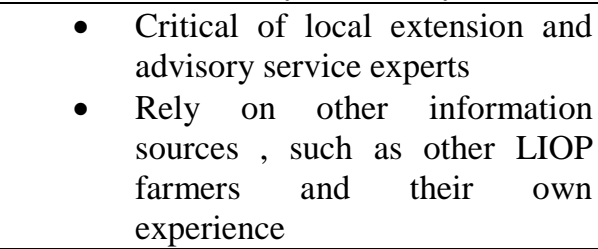 \\
\hline Marketing & $\begin{array}{ll}\text { - } & \text { Ordinary } \\
\text { (supermarkets) } \\
\text { - } & \text { Competition } \\
\text { - } & \text { Export and trade }\end{array}$ & $\begin{array}{ll}\text { - } & \text { Close relation between } \\
\text { producers and consumers } \\
\text { - } & \text { Cooperation } \\
\text { - } & \text { Self-reliance }\end{array}$ \\
\hline Motivations & $\begin{array}{ll}\text { - } & \text { Environmental concern } \\
\text { (ecological modernization) }\end{array}$ & $\begin{array}{lll}\text { - } & \begin{array}{l}\text { Environmental } \\
\text { (biocentric) }\end{array} & \text { concern } \\
\text { - } & \text { Enjoyment } \\
\text { - } & \text { Community values } & \\
\text { - } & \text { Philosophical reasons } & \end{array}$ \\
\hline
\end{tabular}

1.2. Organic Production

In post-modern society, people have begun to reexamine industrial agricultural systems and organic is one path of reaction to modern agriculture. [27, 28] As Cross suggests, policy makers allow deregulated sectors of informality in the economy to function as incubators for new businesses. [1] As organic farming and food consumption grew, it acquired formality through government regulations as the food system acted to satisfy consumer demand with standards and product identity. [29, 30]

In October 2002, USDA implemented the National Organic Foods Production Act. All agricultural products that are sold, labeled, or represented as organic must be compliant with the regulations. [30] Organic production employ strategies, such as crop rotation, beneficial insects, inter-planting, cover crops, natural medicines, multispecies grazing, and rotational grazing, etc. Through these strategies, organic farming aims to improve environmental conditions, food quality and animal welfare. Organized by ecologically minded farmers, organic farming is a social movement that inspires and stimulates the public to reconsider current food production systems and human-nature relations. Alabama, located in southeast U.S., with its distinct culture, history and demographic characteristics, has a unique organic production situation. In Alabama, there are very few USDA certified organic farmers, but there are some conscious and innovative small-scale farmers who are following USDA rules without certification by selling their products as "natural" or "pesticide free".

U.S. Government efforts to boost organic production have focused initially on developing national certification standards to assure consumers of consistent product quality and on facilitating interstate commerce in organically grown products. [31] In Alabama, most farms are small-scale, the average farm size is decreasing, 191 acres in 1997 and 185 acres in 2007, which is much smaller than the national average, compared to 431 acres in 1997 and 418 acres. About 90 percent of farms were less than 500 acres, and 60 percent less than 100 acres. [30] The average organic farm size in Alabama is smaller too. The 12 Alabama certified organic farms comprise 1,529 acres of crop land and 211 acres of pasture. The average organic production acreage in the sample of one survey is 27 acres, and about 70 percent of the farms are less than 10 acres. [29]

In addition, the number of USDA certified organic farmers and certified farmland in Alabama is very small. From 2000 to 2007, there are only 33 farmers registered for the USDA certification program, compared to 12,788 in California. In 2005, among 4.0 million acres of U.S. certified farmland, only 262 acres of Alabama cropland were actually certified as organic, which includes 206 acres of fallow, 4 acres of mixed vegetable crops and 52 acres of unclassified crops. [29, 30] 


\section{METHOD}

The study examines data from mailed survey of Alabama low-input and organically-oriented producers (LIOP). The survey's objectives are to describe their planting or feeding practices and approaches, to assess their information and technical needs, and to profile their marketing strategies. We identified LIOP farms using the Alabama Sustainable Agriculture Network (ASAN) membership lists. ${ }^{1}$ The lists provided a relatively complete inventory of naturally and organically-oriented farms in Alabama. The registration of several years of annual organic vegetable production conferences also supplemented the ASAN lists.

The instrument, developed with assistance of local farmers and ASAN specialists, was mailed in November, 2006. We conducted five mail contacts, consisting of: (1) a prior notification postcard; (2) an initial survey and cover letter; (3) a follow-up thank you/reminder postcard; (4) a second survey and cover letter to non-respondents; and (5) a third survey and cover letter to remaining non-respondents. [32]

Overall, 172 copies of the questionnaire were sent, 131 questionnaire were returned. However, 39 were returned uncompleted as some reported that there was no low-input or organic production on their croplands or they were no longer in operation. The remaining 92 questionnaires gave an effective response rate of $69 \%$ (92/ [172-39]). [32]

In the survey, most variables are measuring by Likert scale. For example, in the organic production motivation question, variables like environmental concern, price premium concern, market demand concern, enjoyment (pride in production), food safety concern, community values and traditions, and philosophical or spiritual reasons, were measured with four-point Likert item " $1=$ None, $4=$ Very important". We operationalized extension support using the measure of farmers' rating of familiarity with public agency programs to assist farmers ( $1=$ Not familiar, $4=$ Very familiar). Some variables about farmers' background are measured by binary items, " $1=$ No, $4=$ Yes".

Descriptive statistics profile Alabama producers' production practices, the reasons they apply LIOP methods, their marketing strategies, information resources, and production problems. The producers' personal background: race, education, use new crop management and familiarity with computers, also are examined. Though analyzing descriptive statistics, we try to understand Alabama production and LIOP.

\section{RESULTS}

3.1. LIOP Production

Table 2 and Table 3 profile LIOP products in this sample. Among 92 respondents, most LIOP are vegetable $(70 \%)$ and fruit (53\%) producers. Their major vegetable crops include tomatoes $(63 \%)$, squash (55\%), peppers $(52 \%)$ and cucumbers (49\%). Almost half of the LIOP plant blueberry as their major fruit crop. Flowers are the most frequent herb crop for Alabama LIOP, about one third of producers grow flowers. However, in this study, very few LIOP producers report planting crops such as hay, wheat, soybean, millet, oats or peanuts.

Their most frequently used production strategies (Table 4) include hand weeding, moving, flaming, smother crops, use manure, crop rotation, and encouraging habitat for beneficial insects, pest monitoring, and intercropping. These strategies are alternatives to the high inputs, machinery industrial production. Through hand weeding, herbicides are avoided, although more labor is needed. Crop rotation helps build healthy and fertile soil and helps diminish pest problems. Using beneficial insects and pest monitoring, unwanted species are kept away. Intercropping - a common practice in developing countries-- makes an effort to increase biodiversity and establish alternative landscape as well as solve pest problems.

Table 2. Farm Enterprises Reported by Sustainable and Organically-Oriented Farmers ( $\mathbf{N = 9 2 )}$

\begin{tabular}{|l|c|l|}
\hline Farm Enterprises & Number & ercent \\
\hline Vegetable crops & 64 & 0.3 \\
\hline Fruits & 48 & 2.7 \\
\hline Herb crops & 39 & 2.9 \\
\hline
\end{tabular}

${ }^{1}$ The Alabama Sustainable Agricultural Network (ASAN) is a nongovernmental organization fostered by Heifer International to expand sustainable agriculture practices among Alabama farmers. It does so by providing education and training, marketing information, and links between urban consumers and rural producers. ASAN attracts most producers through the field day education and all kinds of training, business or educational conferences and workshops. The annual organic vegetable meeting is a major event for Alabama low-income, organic producers.

DOI: $10.9790 / 0837-2108041728 \quad$ www.iosrjournals.org $\quad 20 \mid$ Page


Growing Naturally In a Postmodern Age: How Low-Income Producers Contend With Organic Food

\begin{tabular}{|l|c|l|}
\hline Eggs & 24 & 6.4 \\
\hline Beef & 19 & 1.6 \\
\hline Poultry & 16 & 7.6 \\
\hline Other products & 15 & 6.5 \\
\hline Lamb/sheep/goat & 12 & 3.2 \\
\hline Pork & 7 & .7 \\
\hline Dairy products & 5 & .5 \\
\hline
\end{tabular}

Table 3. Production Items Reported by Sustainable and Organically-Oriented Farmers (N=92)

\begin{tabular}{|c|c|c|}
\hline Products & Number & ercent \\
\hline Tomatoes & 58 & 3.0 \\
\hline Squash & 51 & 5.4 \\
\hline Peppers & 48 & 2.2 \\
\hline Cucumbers & 45 & 8.9 \\
\hline Blueberries & 45 & 8.9 \\
\hline Beans & 42 & 5.7 \\
\hline Sweet corn & 30 & 2.6 \\
\hline Flowers & 30 & 2.6 \\
\hline Other products & 29 & 1.5 \\
\hline Potatoes & 27 & 9.3 \\
\hline Carrots & 26 & 8.3 \\
\hline Grapes & 21 & 2.8 \\
\hline Strawberries & 14 & 5.2 \\
\hline Hay & 11 & 2.0 \\
\hline Asparagus & 10 & 0.9 \\
\hline Apples & 5 & .4 \\
\hline Raspberries & 4 & .3 \\
\hline Soybeans & 3 & .3 \\
\hline Wheat & 2 & .2 \\
\hline Bananas & 1 & \\
\hline
\end{tabular}




\begin{tabular}{|l|c|l|}
\hline & & .1 \\
\hline Millet & 1 & .1 \\
\hline Oats & 1 & .1 \\
\hline Peanuts & 1 & .1 \\
\hline
\end{tabular}

4. Production Techniques Used by Sustainable and Organically-Oriented Farmers (N=92)

\begin{tabular}{lll}
\hline Production Strategy & Number & Percent yes \\
\hline Hand weeding, moving, flaming, smother crops & 74 & 80.4 \\
Use compost/manure & 67 & 72.8 \\
Crop rotation & 60 & 65.2 \\
Encouraging habitat for beneficial insects & 52 & 56.5 \\
Pest monitoring & 47 & 51.1 \\
Interspersed planting & 41 & 44.6 \\
Use approved organic pesticides & 37 & 40.2 \\
Rotational grazing & 25 & 27.2 \\
Conservation tillage & 23 & 25.0 \\
Natural medicines & 20 & 21.7 \\
Breed selection & 19 & 20.7 \\
Multispecies grazing & 18 & 19.6 \\
Use soil inoculants & 15 & 16.3 \\
Release pest predators/parasites & 12 & 13.0 \\
Soil sterilization & 8 & 8.7 \\
Other & 8 & 8.7 \\
\hline
\end{tabular}

3.2. LIOP Characteristics

Selected characteristics of the LIOP are shown in the Table 5. In this study, farm size ranged from 1 acre to 800 acres, the average farm size is 27 acres and $70 \%$ of farms are less than 10 acres. The number of regular laborers on each farm range from 1 to 17 . The average number of labors, including respondents and employees, is 2.5 on each farm.Most producers (76\%) reported they are not familiar with extension support and most of them (75\%) are not county, state or national LIOP organization members. As for business structure, $77 \%$ of the LIOP producers are single family farmers, $60 \%$ of LIOP producers are part time farmers, and their average LIOP time is 9.4 years. Most producers are white. On average, producers are college graduates.

Table 5. Background and Experience Variables, Alabama Sustainable and Organically-Oriented Farmers $(\mathrm{N}=92)$

\begin{tabular}{|c|c|c|c|c|}
\hline Variables & Minimum & Maximum & Mean & $\begin{array}{l}\text { Standard } \\
\text { Deviation }\end{array}$ \\
\hline $\begin{array}{l}\text { Familiar with public agency programs } \\
\text { (1=Not familiar, } 4=\text { Very familiar) }\end{array}$ & 1.0 & 4.0 & 1.9 & 0.96 \\
\hline $\begin{array}{l}\text { Business structure }(1=\text { Single family, } 5= \\
\text { Corporation, other than family })\end{array}$ & 1.0 & 6.0 & 1.5 & 1.10 \\
\hline $\begin{array}{l}\text { Use new crop management ( } 1=\text { Innovator, } \\
5=\text { One of the Last) }\end{array}$ & 1.0 & 5.0 & 2.2 & 1.17 \\
\hline $\begin{array}{l}\text { Full time or part time ( } 1=\text { Full time, } 2=\text { Part } \\
\text { time) }\end{array}$ & 1.0 & 2.0 & 1.6 & 0.49 \\
\hline $\begin{array}{l}\text { LIOP organization membership }(1=\mathrm{No} \text {, } \\
2=\mathrm{Yes})\end{array}$ & 1.0 & 2.0 & 1.3 & 0.44 \\
\hline Farming years & 0.5 & 34.0 & 9.4 & 8.59 \\
\hline Farm acreage & 1.0 & 800.0 & 27.3 & 93.37 \\
\hline Laborers & 1.0 & 17.0 & 2.5 & 2.19 \\
\hline Race $(1=$ Black, $5=$ Other $)$ & 1.0 & 5.0 & 2.1 & 0.60 \\
\hline Gender $(1=$ Female, $2=$ Male $)$ & 1.0 & 2.0 & 1.7 & 0.48 \\
\hline $\begin{array}{l}\text { Education }(1=\text { Some high school or less, } \\
6=\text { Master's degree or more })\end{array}$ & 1.0 & 6.0 & 3.7 & 1.38 \\
\hline Familiarity with computers (1=Not & 1.0 & 4.0 & 3.3 & 0.80 \\
\hline
\end{tabular}


familiar, 4=Very familiar)

Table 6 shows that 30 percent of LIOP follow USDA organic rules, but are not certified. About 45 percent producers reported that they avoid chemical pesticides or synthetic fertilizers. In this sample, about 20 percent of the producers are certified by other agencies, like Naturally Grown Certification or are in the process of being certified. Among 92 LIOP producers, only 4 follow USDA organic rules and are certified.

Table 6. Production Strategies Used by Alabama Sustainable and Organically-Oriented Farmers $(\mathrm{N}=92)$

\begin{tabular}{lll}
\hline Characteristics* & Number & Percent yes \\
\hline Avoid pesticides, use inorganic fertilizer & 59 & 64.1 \\
Avoid pesticides, use organic fertilizer & 52 & 56.5 \\
Follow USDA organic rules, not certified & 35 & 38.0 \\
Follow USDA organic rules, certified by other agencies other than & 17 & 18.5 \\
$\quad$ USDA or in process & 13 & 14.1 \\
Use conventional pesticides or inorganic fertilizer & 7 & 7.6 \\
Follow USDA organic rules, certified or in process &
\end{tabular}

\subsection{Production Motivations}

Among all the reasons (Table 7) for choosing low-input or organic methods, food safety concern was ranked as the most important reason by LIOP producers. Enjoyment and environmental concern were respectively ranked as the second and the third important reasons for LIOP production by Alabama producers. Community values and philosophical reasons were also critical aspects of producer decisions. Market demand concern and price premium concern were ranked comparatively lower than other reasons for choosing LIOP production by Alabama producers. Surprisingly, even USDA certification farmers did not rank price premium and market demand as very important reasons to choose grow organically.

Table 7. Importance of Reasons for Farming LIOP, Alabama Sustainable and Organically-Oriented Farmers (N=92)

\begin{tabular}{|l|l|l|}
\hline \multirow{2}{*}{ Reason } & \multicolumn{2}{|c|}{ Importance* } \\
\cline { 2 - 3 } & Mean & Standard Deviation \\
\hline Food safety concern & 3.8 & 0.46 \\
\hline Enjoyment & 3.7 & 0.52 \\
\hline Environmental concern & 3.6 & 0.68 \\
\hline Community values & 3.2 & 0.85 \\
\hline Philosophical, spiritual reasons & 3.0 & 1.14 \\
\hline Market demand & 3.0 & 0.91 \\
\hline Price premium & 2.8 & 0.95 \\
\hline
\end{tabular}

3.4. Marketing Strategies

$* 1=$ None to $4=$ Very important.

Table 8 shows marketing strategies reported by farmers. Most producers (91\%) sell products locally and their main marketing channels are retail. They primarily sell directly on farm (73\%), in farmers' market (44\%), through a website $(25 \%)$, and through CSAs $(24 \%)$. About 23 percent of farmers sell to restaurants and 22 percent sell to grocery or retail store. Among 92 respondents, only 2 farmers sell to local schools.

Table 8. Marketing Approaches Used by Alabama Sustainable and Organically-Oriented Farmers (N=92)

\begin{tabular}{|l|l|l|}
\hline Marketing Approach & Number & Percent \\
\hline Sell locally & 81 & 91.0 \\
\hline Sell regionally & 17 & 19.1 \\
\hline Sell out of region & 6 & 6.7 \\
\hline Sell directly on farm & 64 & 72.7 \\
\hline Sell in farmers markets & 39 & 44.3 \\
\hline Sell through a website & 22 & 25.0 \\
\hline Sell through CSA & 21 & 23.9 \\
\hline Sell to restaurants & 20 & 22.7 \\
\hline Sell to grocery or retail store & 19 & 21.6 \\
\hline
\end{tabular}


Growing Naturally In a Postmodern Age: How Low-Income Producers Contend With Organic Food

\begin{tabular}{|l|l|l|}
\hline Sell only to family, friends, neighbors & 17 & 19.3 \\
\hline Other marketing channels & 15 & 16.9 \\
\hline Sell from roadside stand & 13 & 14.8 \\
\hline Sell to local school & 2 & 2.3 \\
\hline
\end{tabular}

3.5. Information Sources

Table 9 shows that producers get production information primarily through books, other LIOP farmers, and the Internet. On average, LIOP producers rate extension programs as less important than four other information sources. Producers are more familiar with the Alabama Sustainable Agricultural Network (ASAN) than with public extension agencies. National or state institutions, such as USDA Agricultural Research Service, USDANRCS personal, and private consultant were rated as less important than ASAN by producers.

Table 9. Importance of Information Sources for Organic Farming, Sustainable and Organically-Oriented Farmers $(\mathbf{N}=92)$

\begin{tabular}{|l|c|c|}
\hline Source of Information & \multicolumn{2}{|c|}{ Importance* } \\
\cline { 2 - 3 } & Mean & $\begin{array}{c}\text { Standard } \\
\text { Deviation }\end{array}$ \\
\hline Books or magazines & & 0.84 \\
\hline Other LIOP farmers & 3.2 & 1.05 \\
\hline Internet websites & 2.9 & 0.99 \\
\hline Buyers & 2.7 & 0.97 \\
\hline Alabama Sustainable Agricultural Network (ASAN) & 2.7 & 1.02 \\
\hline University researchers & 2.6 & 0.89 \\
\hline State or county extension personnel & 2.6 & 1.01 \\
\hline USDA agricultural research service & 2.3 & 0.95 \\
\hline USDA-NRCS personnel & 2.2 & 0.94 \\
\hline Private consultant & 2.2 & 0.84 \\
\hline
\end{tabular}

*1=Not important to $4=$ Very important.

When we ask "how do you prefer receiving LIOP management information," most LIOP producers $(91 \%)$ would like to receive low-input and organic production information through printed materials. This is consistent with their rating of books or magazines as the most important information source. Group meetings or seminars were the second most important information source for LIOP producers, since they provide a social platform for LIOP to exchange their production and marketing information and learn each other's successful experience as well as share each other's concerns and problems. Only a few LIOP farmers (8\%) prefer to contact private consultants when they experience production problems. Experts and institutional knowledge are suspect by LIOP, as farmers are more prefer to rely on their knowledge and experience on organic production.

Table 10. Preference for Receiving LIOP Management Information, Alabama Sustainable and Organically-Oriented Farmers (N=92)

\begin{tabular}{|l|c|c|}
\hline Preference of Information Source & Number & Percent \\
\hline Printed materials & 83 & 91.2 \\
\hline Group meetings or seminars & 59 & 64.8 \\
\hline From other LIOP producers & 52 & 57.1 \\
\hline Direct contact with public agency representatives & 35 & 38.5 \\
\hline Direct contact with private consultants & 7 & 7.7 \\
\hline Other & 7 & 7.7 \\
\hline Do not want or need information & 3 & 3.3 \\
\hline
\end{tabular}

\subsection{LIOP Problems}

Though many LIOP may idealize their organic philosophy, we also should pay attention to LIOP problems in the process of production, marketing, and technical support. Rigby, Young and Burton (2001:606-607) concluded that farmers quit organic production, because they were "motivated by lifestyle choice or other ideals, started organic production with little experience and knowledge and subsequently failed to make a sufficient living."During the process of LIOP production, farmers encountered several problems, from production 
difficulties, technical needs, financial support, to marketing conditions. In this study, the respondents were asked to rate typical problems, which were adapted from the literature and based on the Alabama situation. Table 11 shows that drought was rated as the most serious problem in the production process. The study period was one of record drought for the southeast U.S., including Alabama.

Of all the organic production practices, it is hard to access to approved fertilizers and feeds, etc., and this was the greatest challenge for organic growers. Hard to control weeds is the next most severe problem for LIOP. About nearly 50 percent of low input and organically-oriented producers claim weed control is not effective. Difficulty in controlling insects and diseases was another technical hazard, although this was generally rated as less important than weed control. Yield concern also was rated higher than most of other problems by LIOP producers, since yield is directly related to the producers' income.

Lack of product market is the challenge behind production problems. Besides economic reasons, lack of knowledge about organics and uncertainties about organic labeling by consumers may be other factors underlying slow organic development in Alabama. From the post-modern perspective, industrialized operations are criticized, but community-based cooperation is needed to help small farmers make a profit and make rural communities to revive. Most study farmers are small-scale family producers, they usually lack power and resources to expand their marketing beyond direct sales, as only one fifth farmers reported selling to restaurants or grocery stores. As a result, they might lose their market share as well as premium prices.

Financial obstacles are another source of problem for LIOP producers. Relatively high costs of inputs, such as organic seeds, labor as well as certification fees for the annual inspection are also seen as problematic.

Table 11. Severity of Problems that Producers Face, Alabama Sustainable and Organically-Oriented Farmers $(\mathbf{N}=92)$

\begin{tabular}{|l|c|c|}
\hline \multirow{2}{*}{ Problems } & \multicolumn{2}{|c|}{ Severity Rating* } \\
\cline { 2 - 3 } & Mean & $\begin{array}{c}\text { Standard } \\
\text { Deviation }\end{array}$ \\
\hline Drought & & 0.76 \\
\hline Hard to find approved fertilizers, feeds, etc. & 2.4 & 0.74 \\
\hline Hard to control weeds & 2.0 & 0.74 \\
\hline Yield concern & 1.9 & 0.72 \\
\hline Hard to control insects & 1.7 & 0.78 \\
\hline Hard to control disease & 1.7 & 0.76 \\
\hline Lack of product market & 1.6 & 0.78 \\
\hline Lack of cost-share funds & 1.6 & 0.77 \\
\hline Low product prices & 1.5 & 0.61 \\
\hline
\end{tabular}

\section{CONCLUSION}

According to Metzner, "we are in the midst of a transition to an ecological age grounded in the postmodern transformation of the natural sciences, the social sciences, philosophy, and religion," [25] In face of global ecological crisis, such as global warming, overfishing, oil exhausting, etc., people began to rethink their exploitative modern industrial behaviors and human nature relations. Organic farming as an alternative to industrial agriculture, pursues not only an ecologically sustainable agro-system, but also a socially sound environment for both small-scale farmers and rural communities.

Producers have their own views and comparisons on the agro-food systems. Motivated primarily by food safety concern, environmental concern, enjoyment, community values and philosophical reasons, most Alabama low-input and organic farmers choose planting without synthetic pesticides and use organic fertilizers while avoiding USDA certification. Although USDA certification is a meant to distinguish between conventional produces and organic produces, small-scale farmers (27 acres on average in the sample) who want to be certified must supply paperwork, pay consultant fees, and show three years for transition before certification. Many small producers believe that organic standards primarily benefit larger-scale farms, and work as catalyst to conventionalize organic farming.

From a post-modernity perspective, the certification makes "organic" a product of the USDA regulations. It is a bureaucratic, institutional, standard, and artificial behavior, a modern sign of the late modern era. With reductionist definitions of organic production in terms of alternative inputs, current organic standards have neglected the overall agro-ecological sustainability of the organic agro food commodity chain in question. "reflexive modernity" or post-modernity "is characterized by the distribution of risk and individualization...From the individual level it is difficult to grasp the process of standardization, which in turn encourage experiments with new social communities and life forms." [21] Choosing to grow "organically" but 
avoiding USDA certification, Producers have chosen an individualized production path in the current organic movement.

But we still do not know in the future whether most LIOP would like to seek USDA certification if the market demand increased? Whether capitalism will also enter into organic sector in Alabama like what it has done to California organics? [19] Whether the "modern" period will come again after the post-modern era resulted by economic-oriented organic farmers and entrepreneurs? Are Producers individualized, self-reliant and independent from the standardization? In order to answer this question, we need to analyze LIOP motives to employ organic methods.

Alabama LIOP choose organic production not primarily because of economic reason, but because of their ideology, community, and philosophical reasons. These educated growers inspired by the organic movement goals and philosophies, acquire a farming style from their ancestors who farmed before agrochemical revolution.

From these observations, we may conclude Producers adhere to the organic movement philosophies that would classify them as post-modern, but we should also pay attention to the fact that the food safety concern was ranked as the number one motive, which is anthropocentric. The anthropocentric view point is "a central feature of (classical) modernity". [21] This goes back to the human and nature relations, i.e. whether humanity and non-humanity are separated or not. If farmers take "nature as an exterior object", then "there is no need for moral concern." It stimulates our next question that when people mentioned environmental concern, do they view organic farming from an ecological modernization perspective that organic farming as a technical solution to environmental problems, or do they understand it from post-modernity perspective that organic farming is a sustainable way for humans to work with nature, the interior object within the whole production system? Without these data, we cannot answer this question, but community values and philosophical reasons were ranked higher than other reasons. Perhaps this provides evidence that Producers are biocentric and ecologically sustainable minded. As one philosophical farmer from Kaktins' interviews stated: "we are for the earth and aim to pass it on to our children in as good or better condition as when we received it."[30] Through the following analysis, we are led to observe that Producers are independent and have moved beyond of industrial, modern production systems.

Regard to the marketing strategies, most LIOP make direct sales to consumers by words of mouth and their own "no chemicals" advertising. Selling locally through farmers' market, directly on the farm, or through CSAs, LIOP directly contact consumers, endeavoring to establish a special bond and trust with the consumers. These direct sale strategies are well suited to small-scale growers who struggle to offer the quantities and continuities of supply required by supermarkets. [30] Through these market venues, farmers are able to directly contact customers and introduce products to them. Likewise, buying on the farm, consumers may become more conscious of where and how the foods are produced. In this way, suppliers and customers build a special bond through direct sale communications. "The emphasis placed by direct sales on personal interaction, localization and seasonality promotes a sense of integrity and credibility in the organic sector." [31] Third party certification may be less important than the social bonds due to its unclear criterion and uncertainty for consumers.

Power is defined as the ability to set parameters, such as rights, obligations and rules governing processes. On the one hand, such markets channels are an example of "power-resistance reciprocity", suggesting that selling locally through direct markets reduces the power of experts and bureaucrats. Selling in a farmer's market is "a dialogical process of verification, which allows space for small, locally oriented, self-defined chemical-free producers to exist." [32]

On the other hand, through close producer-consumer relations, producers have more power to politicize science and consumption. Though farmers cannot change governing behaviors and conventionalization trends in the organic sector, at least they obtain power by creating their own labels, making their own lives, educating their neighbors about how is food produced, and connecting the food and the community through CSAs. Through close producer-consumer relations, LIOP have more power to influence science and consumption as well as receive reasonable incomes and social recognition. At the same time, Producers primarily rely on their own knowledge and experience as well as other LIOP for production and marketing information, as experts and institutional agencies are ranked as less important information sources by growers.

However, LIOP often face production, marketing, and financial problems; these problems cannot solved just by ideology. According to George Siemon, CEO of Organic Valley, "there is the romance and glamour of small family farms, but we need to make sure that these farms thrive, and that the economic viability of these new models - of CSAs, or organic farming - is there." [33,34] Community-based cooperation and enterprises, are employed by LIOP as a reflection of post-modern society. These strategies, from which farmers benefit more, has a big difference compared to agribusiness corporations, from which capitalists benefit more. At the same time, community-based cooperation emphasizes localization, where local business can survive, more people will be hired locally, and rural communities will revitalize. "A health economy and natural world" should "begin with the rejuvenation or creation of human cultures that are deeply connected to their place, interwoven with its particular constraints and opportunities." [35, 36, 37] At the same time, production and 
marketing difficulties and needs cannot be solved without the cooperation and supports from extension experts, institutions, conscious customers and the whole society. Of course these helps should aim to make sustainable ecology and save the small-scale farmers, instead of aiming to conventionalized organics sectors.

Organic is a postmodern response to industrial agriculture, but remains contested ground as consumer demand draws supermarkets and corporate food systems into the market. Although, organic has not surged in Alabama as it has in the rest of the nation, the market for natural and organic foods has grown in the State. LIOP producers are widely dispersed across Alabama and meet the needs of local networks of regular customers and other direct sales to consumers.

The producers in the LIOP production niche view industrialized agriculture as a different sphere. They seek the organic and natural market for a livelihood, but also have a commitment to advance low-input and organically-oriented production as a societal enterprise. Farmers are using their own production methods and marketing strategies to "alter the agricultural intensification trajectory, to redefine relations between consumers and producers, to act against liberal market philosophy, and to create a viable local rural life without increasing farm size or rationalizing agricultural labor." Future research can clarify the networks of producers and augment their access to consumer markets while retaining the values and ecological benefits of LIOP approaches.

\section{ACKNOWLEDGEMENTS}

Research supported by the Alabama Agricultural Experiment Station, Paul Patterson, Dean and Director

\section{REFERENCES}

[1] P. Midmore. Towards a postmodern agricultural economics. Journal of Agricultural Economics. 47 (1-4), 1996, 1-17.

[2] J. Cross, Street vendors, and postmodernity: conflict and compromise in the global economy. International Journal of Sociology and Social Policy 20 (1/2), 2000, 29 - 51.

[3] J. Lyotard, The postmodern condition: a report on knowledge (Manchester, UK: Manchester University Press. 1984).

[4] L.A. Duram, Good growing: why organic farming works (Lincoln: University of Nebraska Press, 2005).

[5] K. Klonsky, and L. Tourte, Organic agricultural production in the United States: debates and directions, American Journal of Agricultural Economics 80, 1998, 1119-24.

[6] F. Bavec, and Martina Bavec, Organic production and use of alternative crops (Boca Raton, FL: CRC Press, 2006).

[7] S. Fromartz, Organic, Inc.: natural foods and how they grew (New York: Houghton Mifflin Harcourt, 2006).

[8] S. G. Von Essen, and B. W. Auvermann, Health effects from breathing air near CAFOS for feeder cattle or hogs, Journal of Agromedicine 10(4), 2005, 55-64.

[9] L. Cui, Growing naturally in Alabama: needs and possibilities, Master's Thesis, Department of Agricultural Economics and Rural Sociology, Auburn University, Auburn, AL, 2008.

[10] J. Mckenney, Artificial fertility-the environmental costs of industrial fertilizers, in Andrew Kimbrell, (Ed.), Fatal harvest-the tragedy of industrial agriculture (Washington, DC: Island Press, 2002) 239-242

[11] A. Bonanno, D. Constance, and M. Hendrickson. Global agro-food corporations and the state: the Ferruzzi case, Rural Sociology 60(2), 1995, 274-96.

[12] E. M. Wood, The agrarian origins of capitalism, in F. Magdoff, J. B. Foster, and F. H. Buttel (Eds.), Hungry for profit: the agribusiness threat to farmers, food, and the environment (New York: Monthly Review Press, 2000) 23-41.

[13] B. K. Obach, Theoretical interpretation of the growth in organic agriculture: agricultural modernization or an organic treadmill?, Society \& Natural Resources 20:3, 2007, 229-244.

[14] W. Heffernan, Constraints in the Poultry Industry, in H. Schwarzweller, (Ed.), Research in sociology and development (Greenwich, CT: JAI Press, 1984) 237-60.

[15] M. Sarup. An introduction guide to post-structuralism and postmodernism (Atlanta, Georgia: University of Georgia Press, 1993).

[16] G. Spaargaren \& A.P.J. Mol, Sociology, environment, and modernity: ecological modernization as a theory of social change, Society \& Natural Resources 5(4), 1992, 13-29.

[17] K. A. Gould D. N. Pellow, and A. Schnaiberg, Interrogating the treadmill of production: everything you wanted to know about the treadmill but were afraid to ask, Organization Environment 17(3), 2004, 296316. 
[18] F. Jameson, Postmodernism and consumer society, in A. E. Kaplan, (Ed.), Postmodernism and its discontents: theories, practices (London, UK: Verson, 1988).

[19] R.C. Lewontin, The maturing of capitalist agriculture: farmer as proletarian, in F. Magdoff, J. B. Foster, and F. H. Buttel (Eds.), Hungry for profit: the agribusiness threat to farmers, food, and the environment (New York: Monthly Review Press, 2000) 93-106.

[20] D. Goodman, and M. Redclift, The international farm crisis (New York, New York: St. Martin's Press, 1989).

[21] P. Kaltoft, Organic farming in late modernity: at the frontier of modernity or opposing modernity? Sociologia Ruralis 41(1), 20011, 46-58

[22] . S. Lockie, D. Halpin, and R. Gordon, Understanding the market for organic food, in Paul Kristiansen, Acram Taji, and John Reganold, Organic agriculture: a global perspective, (Ed.), (Ithaca, New York: Comstock Publishing Associations, 2006) 243-58

[23] J. Guthman, Agrarian dreams: the paradox of organic farming in California (Berkeley/Los Angeles/London, CA: University of California Press, 2004).

[24] J. Heckman, A history of organic farming: transitions from Sir Albert Howard's War in the Soil to USDA National Organic Program, Renewable Agriculture and Food Systems 21, 143-150.

[25] P. Kaltoft. Values about nature in organic farming practice and knowledge, Sociologia Ruralis 39(1), 1999, 39-53.

[26] P. M. Rosenau, Post-modernism and the social sciences: insights, inroads, and intrusions (Princeton, New Jersey: Princeton University Press, 1992).

[27] J. Heckman, A history of organic farming: transitions from Sir Albert Howard's War in the Soil to USDA National Organic Program, Renewable Agriculture and Food Systems 21, 2006, 143-150.

[28] D. T. Rigby, J. Young, and M. Burton, Why do some agricultural producers abandon organic production systems? An exploration of UK data, School of Economic Studies, University of Manchester, Discussion Paper 0015, September, 2001.

[29] USDA, Organic Production (Washington DC: U.S. Department of Agriculture, Economic Research Service, 2013) http://www.ers.usda.gov/data-products/organic-production/documentation.aspx

[30] USDA, Organic Production (Washington DC: U.S. Department of Agriculture, Economic Research Service, 2005) http://www.ers.usda.gov/Data/Organic/

[31] C. Greene, and A. Kremen, U.S. organic farming in 2000-2001: adoption of certified systems (Washington DC: U.S. Department of Agriculture, Economic Research Service, 2002)

[32] D.A. Dillman, Mail and internet surveys: the tailored design method--update with new internet, visual, and mixed-mode guide (Hoboken, New Jersey: John Wiley, 2011)

[33] I. Audirac, Rural sustainable development: a postmodern alternative, in Ivonne Audirac, (Ed.), Rural sustainable development in America (New York, New York: John Wiley and Sons, Inc., 1997) 3-28.

[34] S. L. Kaktins, Community shared/supported agriculture overcoming the barriers, Master's Thesis, School for Resource and Environmental Studies, Dalhousie University, Halifax, Canada, 1997.

[35] O. Moore, What farmers' markets say about the post-organic movement in Ireland? in G.C. Holt and M. Reed (Ed.), Environmental studies: sociological perspectives of organic agriculture (London, UK: CABI, 2005) $18-36$

[36] D. Buck, C. Getz, and Julie Guthman, From farm to table: the organic vegetable commodity chain of northern California, Sociologia Ruralis 31(2), 1997, 3-20.

[37] L. Oberholtzer, C. Dimitri, and C. Greene. Price premiums hold on as U.S. organic produce market expand (U.S. Department of Agriculture, ERS, Washington, DC: U.S. Government Printing Office, 2005).

[38] P. Kaltoft, and M. Risgaard, Has organic farming modernized itself out of business? Reverting to conventional methods, in Denmark, in G.C. Holt and M. Reed (Ed.), Sociological perspective of organic agriculture (London, UK: CABI, 2006) 126-41;

[39] P, Kaltoft, Organic farming in late modernity: at the frontier of modernity or opposing modernity? Sociologia Ruralis 41(1), 2001, 146-58. 